\title{
Intermediary Governance Space in Relocation Neighbourhoods
}

Beibei Tang

\section{(2) OpenEdition}

\section{Journals}

Electronic version

URL: http://journals.openedition.org/chinaperspectives/9178

DOI: 10.4000/chinaperspectives. 9178

ISSN: 1996-4617

Publisher

Centre d'étude français sur la Chine contemporaine

Printed version

Date of publication: 8 June 2019

Number of pages: $57-65$

ISSN: 2070-3449

\section{Electronic reference}

Beibei Tang, «Intermediary Governance Space in Relocation Neighbourhoods », China Perspectives [Online], 2019-2 | 2019, Online since 10 June 2020, connection on 21 December 2020. URL : http:// journals.openedition.org/chinaperspectives/9178; DOI : https://doi.org/10.4000/chinaperspectives. 9178 


\title{
Intermediary Governance Space in
}

\section{Relocation Neighbourhoods}

\author{
BEIBEI TANG
}

\begin{abstract}
This article examines intermediary governance space in China's urban neighbourhood governance. It identifies new local governance mechanisms and state-society relations through which urban and rural governance intertwine to interact with landless farmers during their introduction to and settlement in existing urban neighbourhoods. Through qualitative data collected in Suzhou, this study reveals the emergence of an intermediate governance space at the neighbourhood level, involving intermediary governance actors and organisations including agents of the Party-state, market groups, and social organisations. In the context of relocation communities, this article examines: how residents' committees are put into place to carry out governance tasks; in what ways the land-losing farmers organise themselves and are mobilised to adjust to a new residential environment, and to what extent conflicts of interest are moderated within the neighbourhoods. The findings suggest dynamics of emerging intermediary governance space and actors in relocation communities. Performing as the liaison between the Party-state and the relocated villagers, the intermediary actors and organisations employ flexible practices and strategies in negotiating the relations between the state, the market, and the citizens produced through neighbourhood governance affairs.
\end{abstract}

KEYWORDS: Neighbourhood governance, urbanisation, relocation communities, mass mobilisation, villagers' group.

\section{Introduction}

In the Chinese context, urban neighbourhoods or residential "communities" - as they are called in Chinese - constitute ambiguous politicaladministrative units. Indeed, they produce a governance space where the Party-state implements policies, interacts with the residents, and monitors public security. Scholars regard this unique political feature of Chinese urban communities as "the roots of the state" (Read 2012) in the form of "government next door" (Tomba 2014). Through its agent residents' committees (juweihui 居委会), the Party-state penetrates neighbourhood governance to pursue public support and extend social control at the most local level of Chinese urban society. With the demise of the public sector's control of urban housing in the 1990s, different types of urban residential communities associated with affordability have become the common scenario in Chinese urban life (Li and Wu 2006; Fleischer 2010; He and Qian 2017). Neighbourhoods, in turn, have been transformed from state-led political campaign grounds to arenas where the state, market, and residents interact regarding community affairs that are closely associated with the specific living environment of the residential communities ( $M a$ and Wu 2005; Li and Huang 2006; He and Lin 2015).

More importantly, along with the changes in social, economic, and political life, neighbourhoods in Chinese cities have become a more complex political arena that accommodates not only the agents of the Party-state such as residents' committees, but also emerging non-state actors and organisations, such as market groups and various forms of social organisations. They constitute important political intermediaries that are positioned somewhere in between the Party-state and ordinary social groups at the level of the street and residential compounds, and facilitate interactions and negotiations between the state and society. Going beyond the influen- tial framework in existing studies of state-society relations in China emphasising the state-society dichotomy (Saich 2000; Ma 2006; Ho and Edmonds 2008; Lu 2008; Unger 2008), this study highlights the complexity of the intermediate governance space and interactions among the intermediary organisations at the neighbourhood level. Instead of considering the interactions between the Party-state and society as a zero-sum game where the gain of one side brings the loss of the other side, this article examines the political and social functions of the intermediate governance space and intermediary organisations, and the process and outcomes they produce in shaping China's evolving state-society relations.

This study examines the intermediate governance space and intermediary organisations by exploring neighbourhood governance mechanisms in socalled "relocation communities (huiqian shequ 回迁社区)." The term "communities" (shequ 社区) used here refers to residential communities in Chinese cities. Relocation communities are a new type of urban neighbourhood directly resulted from urbanisation, and they are commonly observed across different locations in China (Wang 2015; Bai 2018; Chen 2018). In the past two decades, hundreds of thousands of farmers have experienced the expropriation of their farming land and their housing sites (zhaijidi 宅基地) as nationwide urbanisation has proceeded (Lin 2009; Hsing 2010). Those land-losing farmers have usually moved from their village sites to newly developed urban residential compounds and have become new members of Chinese urban society.

The so-called "relocation communities" and their former rural residents have become critical constituents of the official discourse of "citizenisation" (shiminhua 市民化) of the "transforming agricultural population" (nongye zhuanyi renkou 农业转移人口) (State Council 2016). The Party-state's "citizenisation" policy initiatives focus on the specifically targeted populations of land-losing farmers and rural-to-urban migrant workers, and call for sup- 
porting the integration of those groups into urban life in terms of social welfare, economic activities, public services (i.e., the schools), urban administration, and collective property rights. In the context of neighbourhood governance, the "citizenisation" process emphasises applying existing governance practices to long-standing urban neighbourhoods in the newlyestablished relocation communities. Relocation communities are distinct from other urban neighbourhoods due to the continuous existence of village collectives in villagers' daily life, as well as the conflicting rural vs. urban identity of the residents.

Those features have resulted in new dynamics of neighbourhood governance in Chinese cities, with the emergence of intermediary governance space. In the context of relocation communities, as shown in this article, this intermediary governance space accommodates a variety of actors, including para-state actors such as newly-established residents' committees as para-state's agents and former village cadres, market actors such as village collectives, providers of neighbourhood services, including security and property management, and civil groups such as self-organised groups of residents. Focusing on the complexity of the intermediate governance space, this article contributes to existing study of neighbourhood governance in China, which has largely focused on two-way interactions between the state and the residents. This study examines the three-way interactions between the Party-state, intermediate actors, and residents as they shape new governance mechanisms in Chinese neighbourhoods. These emerging strategies of governance give new insights into the sociology of state-society relations in China. I argue that on the one hand, the Party-state reinvents its presence and contacts within society and keeps public order under control by penetrating the intermediate governance space through Party leadership, organisational structure, and mobilisation capacity. On the other hand, flexibility is incorporated into the intermediary governance space, including multiple actors, diverse governance mechanisms, and targeted governance priorities.

Through examining the intermediary governance space in relocation communities, this article also aims to contribute to the study of urbanisation in China and its impact on Chinese society with a stronger focus on the new spaces of urban society. Existing studies on urbanisation in China have overwhelmingly focused on the impact of urbanisation on Chinese rural society, such as land expropriation and village collective economy (Lin 2009; Hsing 2010; Sargeson 2013), as well as the transformation of the rural governance structure (Li 2014; Yang 2014; Wu 2017). This study holds that nationwide urbanisation processes in China in the past two decades have not only shifted the geographical borders of Chinese cities and countryside, but have also reproduced boundaries between rural and urban China in terms of social life and governance. Considering that China's urbanisation rate reached $58 \%$ in 2017 , it is timely and necessary to explore the effect of this process on the other side - a hybrid urban society formed through the incorporation of the former agricultural population, adopting new strategies to accommodate their transforming economic, social, and political life. Focusing on relocation communities, this article identifies new mechanisms through which urban and rural governance features intertwine, and how these mechanisms, as well as local practices, contribute to the reinvention of land-losing farmers' daily life during their settlement in Chinese cities. More specifically, situated in the state-sponsored "citizenisation" campaign, this study explores in what ways and to what extent the changes in neighbourhood life and governance are taking place in Chinese urban neighbourhoods in terms of emerging intermediary actors and organisations in neighbour- hood governance in relocation communities, and as well as how the relocated farmers' new "urban" experiences exert impact on the new aspects of urban life and neighbourhood governance mechanisms.

As suggested in this article, the state-sponsored "citizenisation" discourse reflects the governance mentality of the Party-state, which overwhelmingly focuses on population management and administration arrangements, and pays little attention to challenges in the daily life of land-losing farmers due to the urbanisation process. Despite their passive position in the "citizenisation" discourse, the relocated farmers' everyday life is closely associated with the management and administrative tasks emphasised in the "citizenisation" discourse. In this scenario, the approach of intermediate governance space addresses the actions of the state side on the one hand, and the daily experiences of the relocated farmers on the other hand. Those two aspects, as the rest of this article shows, are not mutually exclusive. Instead, they interact with each other to produce complex governance dynamics under China's urbanisation.

Through a case study of Suzhou's Wujiang District (qu 区), this article examines how the "citizenisation" scheme is carried out among relocated farmers through three major aspects of community life in relocation communities - the establishment of an urban administrative apparatus, the residents' social life, and property management issues. Between 2002 and 2012, Wujiang went through land expropriation, relocation of land-losing farmers, and development of relocation housing compounds. This study selected $\mathrm{H}$ neighbourhood (1) as a case study, because $\mathrm{H}$ neighbourhood was the designated residential project for relocated farmers in Wujiang. $\mathrm{H}$ neighbourhood accommodates four relocation communities and 4,500 relocated households. In addition, $\mathrm{H}$ neighbourhood is the key experimental site for the Wujiang government's relocation settlement project and "citizenisation" project. On the one hand, $\mathrm{H}$ neighbourhood has experienced a rather ordinary urbanisation process as observed elsewhere in the country, going through "village to community" transition, relocation resettlement, and the establishment of an urban governance structure in the relocated communities. On the other hand, $\mathrm{H}$ neighbourhood presents specific complexities such as the local arrangements for remaining village collective assets, the co-existence of complete and incomplete "village to community" transition, and the issue of sufficient financial support from the district government.

One relocation neighbourhood is inadequate to build a general theorisation on the urban features of relocation communities in China. Moreover, the unique and complex features of $\mathrm{H}$ neighbourhood show the limitations of explaining the changing neighbourhood governance as a whole. But $\mathrm{H}$ neighbourhood does present a few shared common practices of governance that reveal key aspects of power exercise in relocation communities, especially since $\mathrm{H}$ neighbourhood is part of the government's "citizenisation" scheme. Also, $\mathrm{H}$ neighbourhood reflects a local diversity and flexibility that is common in local governance in China. The empirical data used in this study is based on a qualitative study conducted from 2016 to 2017 in four relocation communities accommodating 4,500 households. In addition to local official documents, 38 in-depth interviews were conducted with local government officials, residents' committee staff, village collective representatives, and residents. Two focused group interviews were conducted with village collective representatives and residents, respectively. Despite their limited number, the in-depth interviews provided detailed information on how the new governance structure was established in the relocation com-

1. A pseudonym is used here. 
munities, and in what ways and to what extent an intermediary governance space was produced through the interactions among different actors.

\section{Urbanisation and the emergence of relocation communities}

The most common characteristic of China's nationwide urbanisation campaign is the expropriation of rural land for commercial and urban residential projects (Gu and Wu 2010; Chung and Unger 2013). In some cases, the land expropriation only applied to farming land, while villagers kept their residence registered in the village, as many cases in the Pearl River Delta suggested. In other cases, the land expropriation took place in a more comprehensive form through acquisition of both farming land and the sites of villagers' homes. The latter practices are more commonly observed in other regions. The villagers were then offered alternative residence arrangements and moved to newly-built urban residential compounds composed of multi-story apartment buildings, common areas, and property management and maintenance services. Usually the alternative residential arrangements are real estate development projects designed especially, and in most cases exclusively, for land-losing farmers. In Chinese cities today, with modern residential compounds becoming the norm, there is gradually less noticeable difference between the physical appearance of relocation housing and commercial housing. But local residents have no difficulty identifying relocation housing, which is always grouped together with established territorial and social boundaries between its residents and other urban residents.

Wujiang is at the southern end of Suzhou, one of the most prosperous cities in the Yangzi River Delta and in China. Wujiang is located at the intersection of Suzhou, Shanghai, and Zhejiang. A township-level city since 1992, it became an administrative district (qu 区) of Suzhou in 2012. Since the economic reforms initiated in the late 1970s, Wujiang has experienced rapid urbanisation, with an urbanisation rate exceeding $70 \%$ by 2016. In 2013, the new administrative label "Wujiang Tai Lake New Town" was adopted. The current Tai Lake New Town administers what were previously the townships of Hengshan and Songling in Wujiang. The administration covers 200 square kilometres, with a registered population of 200,000 under four street offices (jiedao 街道), (2) 38 villages, and 21 urban residential communities (shequ 社区).

The development of relocation housing in Tai Lake New Town started in 2002 and lasted for a decade. For Tai Lake New Town, as in other parts of the country, the main method for carrying out urbanisation was through expropriation of rural land for urban residential and real estate projects. The land expropriation directly resulted in two rounds of so-called "village to (urban) communities" (cun gai ju 村改居) (Cao and Wang 2010; Huang and Jiang 2011; Xu 2012) in 2002 and 2007, respectively. The "villages to communities" process switched the land-losing villagers to the urban administrative system, as well as moving them to newly-built urban residential communities - the "relocation communities." In general, relocation communities usually occupy a larger area, and accommodate more households and more diverse residents than the previous villages. Their residents are mainly land-losing farmers, and the number of residents is usually quite large compared to their former villages. In most cases, the relocation housing is part of the compensation deal offered to land-losing farmers as an alternative residential arrangement, in addition to monetary compensation for their farming land. Across the country, standards of monetary compen- sation and the quantity and size of compensation housing vary significantly from one locale to the other. One phenomenon appears to be consistent, however: the emergence of relocation communities and the introduction of land-losing farmers to urban society has had a significant impact on urban life and neighbourhood governance in Chinese cities, as this article will illustrate.

As the largest villagers' relocation project, $\mathrm{H}$ neighbourhood occupies an area of 44 square kilometres out of a planned construction area of 80 square kilometres. It is located in the heart of the largest newly-developed residential zone in Tai Lake New Town. Designed in the form of modern, commercial housing, $\mathrm{H}$ neighbourhood is the designated residential project for relocated farmers in Wujiang. More than $80 \%$ of the residential developments in $\mathrm{H}$ neighbourhood are relocation communities. $\mathrm{H}$ neighbourhood now accommodates four relocation communities and 4,500 relocated households. The $\mathrm{H}$ neighbourhood development project started in 2008. The first group of relocated farmer residents moved in 2010, and the last group of residents moved in around 2012. Villagers in $\mathrm{H}$ neighbourhood were given the choice of which relocation community in all of Wujiang they would like to move into, and $70 \%$ of the villagers chose to stay in $\mathrm{H}$ neighbourhood. Today there are approximately 6,800 registered residents. In some cases, the residents are from the same village, while in others, they have been grouped with residents from different villages. $H$ neighbourhood has therefore become the hub of relocated communities in Wujiang.

Nationwide, land expropriation is usually accompanied by switching the administrative status of the villagers and their villages from "agricultural (rural)" to "non-agricultural (urban)." Local governments have used the promise of urban household registration (hukou 户口) status and its accompanying privileges (Whyte 2010) as a powerful bargaining tool when urging villagers to accept land expropriation deals. And indeed, in most cases, land expropriation has gone hand-in-hand with the transfer of the villagers' household registration status from rural to urban. In addition to urban hukou status, an urban governance system has been introduced to the relocated farmers. That is, urban residents' committees (juweihui 居委会), as the local agents supervised by the municipal government at the neighbourhood level, have replaced the traditional village committees (cunweihui 村委会) in dealing with the daily affairs of the relocated farmers. With their new urban household registration, the relocated farmers are able, in principle, to access the urban employment and welfare system.

Tai Lake New Town has its own complexity in which so-called "complete villages to communities" (wanquan cun gai ju 完全村改居), where residents are registered with an urban household registration, co-exist with "incomplete villages to communities" (bu wanquan cun gai ju 不完全村改居), where residents maintain their rural household registration but can still benefit from urban social security, i.e., old-age insurance and medical insurance. In $\mathrm{H}$ neighbourhood, the great majority of relocated villagers living in the urban (relocation) housing compounds retain their rural household registration. This is largely due to the fact that the protracted land expropriation process has not been completed yet, and the remaining land and collective assets are still owned by the village collectives.

For the relocated farmers, urban administration and the identity of "being an urban citizen" have been contested in their everyday life in relocation communities. Interviews with the residents suggest that, on the one hand, they are more likely to recognise their "urban citizen" status due to their

2. Street office is the lowest level of city government in China. 
urban residence and social security entitlements, despite the fact that their household registration status remains "rural." But on the other hand, the relocated farmers still show strong attachment to their village collectives due to the continuing existence of village collective income generated through the remaining land and collective assets. Meanwhile, residents in relocation communities find themselves dealing with new groups and organisations in their neighbourhoods, such as residents' committees and property management companies. They are also experiencing different patterns of social interaction in the community as part of the changing governance dynamics. Altogether those experiences are significantly shaping urban life and governance in relocation neighbourhoods, as the rest of the article explains in detail.

\section{Establishment of urban governance in relocation communities}

The complexity observed in $\mathrm{H}$ neighbourhood is in line with the State Council's protracted call for flexible practices and policies supporting the state-sponsored discourse of "citizenisation" of the "transforming agricultural population" (State Council 2016). More importantly, those policy initiatives have officially endorsed and encouraged local flexibility in carrying out the "citizenisation" process. Local governments, based on experimental practices across the country in previous years, have therefore become a major driving force in the social and political production of the so-called "new urban citizens" (xin shimin 新市民). In particular, relocation communities have become the most local level for implementing various local government programs of "citizenisation" and a key contested ground of the state-led "citizenisation" discourse.

$\mathrm{H}$ neighbourhood, due to its large number of relocation residents, became a major project of Wujiang government's "citizenisation" scheme. During interviews with local officials, residents' committee staff, and former village committee members, one comment that came up many times was that the change of household registration or moving into residential communities alone does not make the relocated farmers "urban citizens"; what is needed is to change their "mindset" (sixiang 思想) and "behaviour" (xingwei 行为) to fit the official portrait of "urban citizens." (3) In Wujiang, the establishment of urban administration and property management services - both issues are new to residents in relocation communities - have become key to the social and political production of the "new urban citizens."

Residents' committees, as the state's semi-formal agent penetrating urban neighbourhoods, are the cornerstones of the Chinese urban administrative structure (Read 2012; Tomba 2014). For each urban residential community, there is a residents' committee carrying out administrative tasks and monitoring residents to prevent social discontent from escalating to collective action. Directly under the supervision of the street office, which is the lowest level of the official state apparatus in Chinese cities, residents' committees are composed of around a dozen staff hired by the local government. Residents' committee staff do not have the status of public servants, nor do they have any decision-making authority, and they are "in the middle of everything" (Audin 2015). On behalf of the public authorities, residents' committees interact with residents on a regular basis and expand the social base of China's urban administration through their social networks among the residents. This regular contact, acquaintance, and social networking are significant for carrying out intermediary governance in Chinese urban neighbourhoods.
As land-losing farmers moved into the relocation neighbourhoods, the first task of the local government was to establish residents' committees in order to implement various governance programs in those communities, as well as to mediate or resolve discontent and conflicts between the residents. However, since the land expropriation process took up to a decade to complete, and the residents moved in according to different waves of relocation, the relocation communities initially faced the situation of not having a large enough registered population to establish residents' committees. Usually the establishment process took one or two years. In addition, there was a gap between relocated farmers' change of residence to an urban setting and their attachment to their former rural community. Taking $\mathrm{H}$ relocation neighbourhood as an example, residents came from more than ten surrounding villages. During the first couple of years after they moved in, the residents only recognised governance by their own village committees and showed resistance to the residents' committee staff "from outside" who were assigned to the communities by the district government. ${ }^{(4)}$ Local social networks are essential in the intermediary work of the staff of residents' committees, who were appointed by the state authorities but had to be accepted and recognised by the residents. In a new space like $\mathrm{H}$ neighbourhood, the legitimacy of former social networks was still dominant, and simple top-down implementation of a purely systematic administrative office was difficult.

As a result, the Wujiang government put the establishment of residents' committees in relocation communities temporarily on hold. Instead, they introduced a multi-functional community service centre (shequ fuwu zhongxin 社区服务中心) in early 2015 to establish an urban proto-administrative urban apparatus in $\mathrm{H}$ neighbourhood. The community service centre serves as administrative headquarters for the relocation communities. Under the leadership and supervision of $\mathrm{H}$ street office, the centre administers four relocation communities with 4,500 households, and it occupies 10.9 square kilometres, providing neighbourhood services and administration offices. The community service centre offers one-stop services to residents of the relocation communities. Instead of going to different government offices, the residents can go to the designated desks of different government offices at the community service centre for all administrative services.

Sufficient funding from the local government to support the expense of public services has been crucial for the transition period of relocation neighbourhoods. If the remaining village collective economy does not bring substantial income, urban administration in relocation communities then relies heavily on government budget. Total investment for the entire $\mathrm{H}$ community service centre was around 25 million yuan. Since 2010, for communities with 2,000 to 2,500 households, the administrative budget expense has been 3.5 to 4 million yuan per year. Funding has been provided entirely by the Wujiang district government. The district government also requires that all relocation community residents' committee offices should allocate at least 500 square meters to cover the needs for administrative tasks and residents' social activities. Sufficient funding from the local government to support new expenses of community services makes the new urban governance structure and practices more acceptable by relocated farmer residents.

Although the establishment of residents' committees in $\mathrm{H}$ neighbourhood is on hold, there are two de facto residents' committees - under the name

\footnotetext{
3. Interview with government officials, No. 2-4, June 2016.

4. Interviews with the residents, No. 9-12, July 2016.
} 
of "working groups" (gongzuo xiaozu 工作小组) - under the supervision of the community service centre to carry out working tasks in individual relocation communities. The two working groups have 15 staff who supervise property management and carry out other administrative duties. The two working groups are composed of former village committee members. They work under the supervision of $\mathrm{H}$ street office. Through this practice, the relocation communities have extended the former village governance structure to the urban setting. To a certain extent, this arrangement has helped reduce villagers' resistance to the newly-established urban administration. The two working groups, together with the community service centre, serve as intermediaries of the governance structure in the relocation communities. On the one hand, there is a deliberate de-emphasis on the components of official urban administration, while highlighting the "public service" function of those organisations. On the other hand, the involvement of former village cadres mixed with the community service centre staff hired by the $\mathrm{H}$ street office has, to a certain extent, made the reach of the state into relocation communities possible.

Beyond the neighbourhood governance structure, the intermediaries are also involved in non-official organisations in relocation communities, i.e., (former) village collective economy. The village collective economy, which used to play a crucial role in shaping village governance, still exerts significant impact on governance mechanisms in relocation communities. In Suzhou, due to the local land expropriation policies and compensation arrangements, only a proportion (10\% to $30 \%$ ) of the compensation fund was distributed to individual villagers. Meanwhile, an investment company associated with the local government hoards and manages the rest of the compensation fund and distributes interest and investment profits to villagers every year. Instead of individual villages, the company pools and manages resources and organises investment projects for the entire relocation neighbourhood. The village collectives are therefore not directly involved in the operation of the projects, but facilitate the distribution of annual interest and bonuses to the relocation community residents. The former village committee members, as representatives of their village collective economy (unappropriated land, assets, property rental income), serve as a communication channel between the relocated villagers and the investment company.

In addition to collective economic activities, one other major form of inherited rural governance is that the new urban administration relies heavily on former village elites to establish communication and trust with the residents. For example, keeping a record of residents has been a major task and challenge for relocated communities. Residents usually moved in at different times, and it is common for residents to rent out one of their compensation housing units to migrant workers for extra income. Therefore, the new urban administration is very dependent on the former village committees to recruit resident volunteers to facilitate collecting and reporting residents' information. To establish a close relationship with residents, $\mathrm{H}$ neighbourhood recruits resident-volunteers to cover 40-50 households each, and liaison staff from the two working groups to cover 150-170 households each. The liaison staff receive 3,000 yuan a year and the resident-volunteers receive an annual payment of a few hundred to 1,000 yuan by way of honoraria. Those resident-volunteers include former production team leaders and former village committee members. As a result, replacing the urban administrative structure, the governance system in relocated communities takes the form of a mix of urban administration tasks and rural collective economic activities, as well as urban government leadership and the remnants of rural government authority.
The involvement of former village elites in the newly established urban governance structure serves two intermediary functions of governance in relocation communities. On the one hand, the co-optation of former village elites into newly-established urban neighbourhood governance to a certain extent has resulted in greater acceptance of urban neighbourhood governance arrangements and less resistance from the land-losing farmers. On the other hand, former village elites - as representatives of the remaining village collective economy - exercise a certain autonomy in the intermediary governance space. The extent to which they maintain their autonomy largely depends on the amount of collective assets they manage to keep after the land appropriation and how much profit is generated. In $\mathrm{H}$ neighbourhood, as discussed above, the investment company associated with the local government oversees the management of the remaining assets of the relocated villages. To a certain extent, that has weakened the autonomy of former village cadres in the intermediary space. In this case, rather than extending their influence on rural governance, the former village elites are more easily co-opted and now operate as liaisons between the local government and the villagers, facilitating the transformation from rural to urban governance.

\section{"Citizenisation" and community life}

Community life in relocation communities constitutes one main target of the "citizenisation" discourse. From the perspective of local governance, the "citizenisation" process involves resident mobilisation, residents' participation in community affairs, and conflict resolution in urban neighbourhoods, while from the perspective of the relocated farmers, the urban administration and the identity of "being an urban citizen" has remained difficult and has been contested through their everyday life in relocation communities. The significance of intermediary governance space is as an arena where official discourse and residents' narratives as citizens encounter each other. The change in their economic activities and residential settings has brought new forms of community activity and interaction between the residents, which are largely associated with their new residence and living environment and have significantly influenced the construction of their "urban" identity.

Since urban residents' work life is separate from their private life in residential communities, residents' committees focus exclusively on residents' community activities apart from their employment. In relocation neighbourhoods, however, the newly established residents' committees face a situation in which residents' community activities are still closely attached to their collective assets and economic activities due to their (remaining) land ownership and their village collective's contribution to their social security (Hsing 2010; Tang 2015). The extent to which the relocated farmers' socio-economic wellbeing is dependent on their village collective economy plays an essential role in shaping the "urban identity" of the relocated farmers. In Suzhou, urban social services were provided as part of the compensation to the villagers during land expropriation. Since village collectives are no longer involved in the provision of social security to their villagers, residents are more likely to recognise and accept their "urban citizen" status, regardless of their household registration status. As one resident said: "My household registration booklet still says that I am a rural person. But I have joined the urban pension and medical insurance schemes. So I consider myself an urban person now." (5)

5. Interview with resident, No. 1, September 2016. 
For those relocated farmers, the transformation of their daily activities and community life plays a significant role in shaping their "new citizen" identity. The relocated farmers find themselves experiencing different modes of social interactions and community life when dealing with new groups and organisations in their neighbourhoods. They no longer work in the fields and they are unfamiliar with their neighbours who moved from other villages. The younger generation who are in their 20s and 30 s usually find jobs in the cities and spend very limited time in the community. Many young people even move out to live somewhere closer to work. For those who are in their 40s and 50s, men are more likely to be self-employed or to find casual work than women. There are very limited job opportunities for women in this age group. Most end up living on their compensation, annual bonus/interest, and rental income. Thus, middle-aged women and senior residents have become two major resident groups who spend most of their time in relocation communities.

As in other urban residential communities, recreational activities have gained popularity among the residents in relocation communities. Two types of activities are most popular: group dance and choir, and table tennis. Those who join the group dance and choir are mostly women, while table tennis mainly attracts male players. Usually residents organise themselves to carry out those activities, and residents' committees assist them by providing space and facilities for the activities. The community service centre in $\mathrm{H}$ neighbourhood serves this function very well. There are separate rooms for group dance and choir, as well as an open area occupied by four table tennis tables. In general, there is an open-door policy where residents can come and use the facilities anytime. If there is popular demand, then the residents need to make a booking in advance. In addition, the community service centre also provides space, facilities, and coordination for residents' social activities.

These kinds of recreational activities play an essential role in helping relocated villagers adapt to their new living environment and expand their social networks. It has become the primary way for them to get to know fellow residents from different villages. Active participants usually spend one afternoon with their group members, five or six days a week. Each community has at least three to four recreational activity groups, with the number of participants ranging from less than ten to more than 50. Through participation in those activities, a new community identity gradually emerges. During conversations with residents who regularly participate in those recreational activities, it is more common to hear those residents address themselves as "formerly from village X" and to refer to their residential community as "our community." With the growth of recreational activity groups, in some cases the groups sign up for performances or contests outside the neighbourhood. When their activities go beyond their own residential community, "we are from community X" replaces "I am formerly from village X."

For the staff of residents' committees, these recreational activities provide the best opportunities for them to get acquainted with residents and recruit resident-volunteers to facilitate their everyday work. Therefore, residents' committees in relocation communities are very supportive of these leisure activities. In some cases, residents' committee staff help the groups establish contacts and find opportunities for them to perform or join contests outside their neighbourhood. In general, the residents welcome the coordinating role of residents' committees. When asked what they would like the residents' committees to do for them, residents in different neighbourhoods expressed one common request: they would like the residents' committees to organise day trips for them. One resident said:
When I used to work in the field every day, I had no time for those things (recreational/leisure activities). Now that I no longer have work to do, I would like to see different places in the city. But I know little about the city, where to go and what to do. So it would be nice if our residents' committee could organise day trips for us, so we could enjoy the trip with no worries. ${ }^{(6)}$

This point of view is very common among middle-aged and senior residents. Moreover, by helping coordinate recreational activities for the relocated farmers, the local government manages to maintain a close relationship with certain groups of residents, who in turn help carry out government tasks in the neighbourhoods. Resident mobilisation has been a key feature of urban grassroots governance, in parallel to the mass mobilisation carried out at urban residents' workplaces (Audin 2017). In relocation neighbourhoods, residents' committees face a larger group of residents who have no alternative employment opportunities. Unlike urban low-income residents, this group of residents is economically better off. This group has therefore become the target group for residents' committees to mobilise and organise. Through participation in recreational activity groups, relocated farmers have experienced a change of lifestyles, especially leisure activities. Residents' hobby groups are similar to residents' social activities in most urban residential communities. From this aspect, the boundary between rural and urban has become insignificant.

\section{"Citizenisation" and property management}

Relocation communities, designed and operated in similar ways to other urban residential estates, face similar needs for professional property management and maintenance, which is a new concept for relocated villagers who have moved from largely self-managed and self-maintained village housing. How to deal with those issues commonly observed in other urban neighbourhoods has become one key aspect of the "citizenisation" scheme, which aims to illustrate in what ways and to what extent relocation communities are integrated into urban neighbourhood governance in terms of governance issues. In other words, the "citizenisation" discourse expects relocated farmers to act and behave similarly to their urban counterparts when dealing with neighbourhood governance affairs.

For example, in Chinese cities today, it has become the norm for modern residential neighbourhoods to introduce professional services to manage community facilities provided by property management companies. As a nationwide phenomenon, real estate developers usually take for granted their right to leave in place a property-management company that would operate indefinitely. In the absence of any competition, these firms are well positioned to reap handsome profits from management fees. Management companies have therefore become the main target when residents are dissatisfied with problems such as poor maintenance of housing estate facilities, excessively high management fees, and poor quality of services. Across different localities, it has been consistently observed that Chinese urban residents - especially middle-class residents - show collective resistance against inadequate maintenance of their housing estate facilities, excessive management fees, and poor quality of management. Chinese urban neighbourhoods have become an important contesting ground where residents interact with the state and each other through their participation in com-

6. Interview with resident, No. 13, April 2017. 
munity governance and homeowner activism (Read 2003; Tomba 2005; Pow 2009).

In relocation communities, the introduction of property management companies and the collection of property management fees has become an ongoing difficult mission to accomplish. For relocated farmers, land expropriation and relocation is usually accompanied by loss of income. Residents usually consider the property management fee an extra expense and refuse to pay. ${ }^{(7)}$ Also, property management in residential communities is a new concept for relocated farmers, who relied entirely on self-maintenance of their residential properties and environment. ${ }^{(8)}$ Therefore, the collection of property management fees in relocation communities has become an impossible mission. None of the relocation communities in $\mathrm{H}$ neighbourhood had successfully collected their property management fees - which were set around 0.2-0.4 yuan per square meter per month. As to the selection of property management companies, some communities preferred to outsource the work to property management companies, while other communities preferred to operate on their own by hiring security guards, cleaning staff, and maintenance staff among the residents.

To deal with the situation, $\mathrm{H}$ street office decided to suspend the collection of property management fees for the time being, with the alternative of collecting annual cleaning service fees of 120 yuan per household. The local government subsidises the property management fee, which is 0.3 yuan per square meter per month for the residents. The street office also suggested that each residential community hire their own security guards and cleaning staff, instead of hiring property management companies. Each community was encouraged to recruit security and maintenance staff among their residents, which would also help provide employment opportunities. Moreover, having residents do the work could be expected to reduce conflicts between the residents and property management companies. ${ }^{(9)}$ The two working groups work with the property management office of the district government in supervising property management services in the relocation communities.

At the current stage, the local government does not encourage establishing homeowners' associations in relocation communities to deal with property management companies, ${ }^{(10)}$ which is the norm in urban residential communities in China today (Read 2007). This is partly due to the heavy subsidies of property management fees provided by the local government. More importantly, the absence of homeowners' associations in those communities to a certain extent helps reduce collective conflicts between the residents and the government regarding property management issues. So far, there is a lack of clear policy orientation regarding how long the government subsidy will last and whether and to what extent there will be a need to introduce professional property management services into relocation communities. As a result, the residents' committee staff are unenthusiastic about establishing homeowners' associations in relocation communities. While homeowners' associations have become a common self-organised group for residents of other urban residential communities, they have not yet found their place in relocation communities.

Compared to other modern urban residential communities, especially urban middle-class gated communities where major conflicts take place between residents and property management companies, relocation neighbourhoods feature disputes between residents as well as conflicts between local residents and "outsider" tenants. Observations and interviews from my fieldwork suggest that disputes between residents are largely due to residents' various reactions to their changing living environment. For exam- ple, how to deal with the common or shared area in buildings and residential communities has become a major cause of dispute among residents. Some residents turned the hallway of their apartment building into their private storage area and blocked entrances and fire exits. In some cases, residents disposed of garbage in the common area of residential compounds. In $\mathrm{H}$ neighbourhood, e-bikes are very popular among the residents, but not every building is equipped with e-bike chargers in the basement. Some residents therefore installed illegal chargers in their building basement, causing safety concerns and complaints from other residents. In addition, water leakage from apartments is a common problem in almost all urban residential communities. Moreover, since the number of migrant worker tenants is nearly as great as that of local residents, disputes between landlords and tenants, or in other words, between locals and outsiders, emerged as well. Locals complained that outsiders brought crime to the neighbourhood (11) - a common bias that urban residents hold against rural-to-urban migrant workers. Locals also complained that migrant tenants were too noisy at night because they came back late. ${ }^{(12)}$ Migrant tenants do not often communicate with the locals. Due to multiple demands from residents, dependence on government subsidies, and the ineffectiveness or non-existence of property management services, these problems are usually left to residents themselves to resolve.

In these kinds of disputes, residents' committees usually intervene and carry out mediation. Former village committee members then serve as the key middlemen and resident volunteers to facilitate communication. In some cases, resident volunteers directly participate in mediation of conflicts. In other cases, they are not directly involved in the mediation process. Instead, they actively monitor residents' activities and report to the residents' committees if they spot potential collective incidents. When mediating disputes between residents and within families, resident volunteers have a unique advantage - a rich local knowledge and dense social networks within the community. They know the villagers well, and their past work experience as village cadres has endowed them with strong power relations, largely owing to the village committee's previous significant leading role in village economic life. In addition, the two working groups mobilise well-respected elderly residents, better-educated residents, and key figures in lineage groups to mediate disputes. As in other urban neighbourhoods, when it comes to collective disputes, the residents' committees' volunteer networks perform the crucial task of political surveillance in relocation communities, preventing collective disputes from escalating into larger-scale social unrest.

\section{Conclusion}

This article examines China's changing urban neighbourhood governance patterns in the context of rapid urbanisation, with a particular focus on the rise of an intermediary governance space between state and civil society and its dynamics in the case of newly-emerged relocation communities. The nationwide urbanisation processes in China in the past two decades have fundamentally redefined economic, social, and political life in Chinese society. In the context of neighbourhood governance, as this article shows,

\footnotetext{
7. Interview with residents, No. 14-17, July 2017.

Interviews with residents, No. 4-9, July 2016.

Interviews with Residents' Committee staff, No. 10-11, July 2016.

0. Interviews with local government officials, No. 1-3, June 2017.

1. Interviews with the residents, No.15-17, August 2016, June 2017.

12. Interviews with the residents, No. 18-22, August 2016, June 2017.
} 
the urbanisation process has introduced diverse actors - both agents of the Party-state and non-state actors - who negotiate the relations between the state, the market, and the citizens produced through neighbourhood governance affairs, and constitute the key actors of intermediary governance space in the neighbourhoods. Serving as a liaison between the Partystate and the relocated villagers, those intermediary actors and organisations employ flexible practices and strategies in participating governance in relocated communities, and further shape the neighbourhood governance mechanisms and outcomes.

Taking Wujiang district of Suzhou as a case study, this article illustrates how urban administration structures are put into place to carry out governance tasks; in what ways the land-losing farmers organise themselves and are mobilised to adjust to new residential environment; and to what extent the land-losing farmers' new "urban" identify is constructed along the lines of the state-sponsored "citizenisation" discourse. During this process, an intermediate governance space has emerged. This intermediate governance space involves a complex process of interaction between the state initiatives of constructing a new "urban" image of the relocated farmers and the relocated farmers' "rural to urban" identity transformation through their everyday life in new urban neighbourhoods. During this process, intermediate actors and organisations such as former village cadres and village collectives play a significant role in shaping governance mechanisms in relocation communities. As the liaison between the local state and former villagers, they influence the establishment of a governance structure in the neighbourhood, negotiation between the residents and local government, and mobilisation of resident volunteers and public support in relocation communities. As a result, the practice of state-sponsored "citizenisation" discourse, as shown in this study, is far more complicated than land expropriation and the establishment of urban governance structure in relocation communities. Rather, it is a gradual and complicated process that involves multiple actors, flexible practices, and varying outcomes. The process of citizenisation does offer a certain level of autonomy constrained by the administrative structure, funding arrangements for neighbourhood governance, and the profitability of remaining village collective assets. These factors all influence the prospect of urbanisation in China.

In the context of the "citizenisation" discourse led by the Party-state, this study identifies the strength and flexibility of the intermediary governance space in relocation communities. To a large extent, citizenisation is a process of co-existence of integration and rural-versus-urban segregation. In Suzhou's case, the relocated farmers have experienced dramatic changes in their economic life and residential environment, but not much in their household registration status. The continuing existence (formally and infor- mally) of previous village governance powers still plays a crucial role in shaping governance mechanisms in the new neighbourhoods, and former village political elites have significant impact on resident mobilisation and self-organisation. In addition, the local political economy, in particular the trajectories of distribution of village collective assets, is one key factor determining the new "urban" identity of relocated farmers. These findings highlight the dynamic, strategic play between the villagers, former village political elites, and the local state in redefining boundaries between and categories of rural and urban China. Meanwhile, new associational life in relocation communities plays a significant role in carrying out the citizenisation process at the neighbourhood level. An ideal site for the integration of relocated farmers into urban life is the residential communities where they gradually transform their socialisation, perceptions, and identity. In addition to recreational activities that are already successful, relocation communities are facing the challenges of how to expand community activities to multiple categories (i.e., decision-making in community affairs) and diverse resident groups (i.e., younger and/or male residents). The expansion of relocated associational life in their residential communities not only contributes to the transformation of relocated farmers' lifestyles, but more importantly, it helps them build a sense of belonging to urban society and a perception and identity of being a citizen.

The case studies presented here show the mechanisms of intermediary governance space through which the state and intermediate actors interact with each other; the intermediate governance space mediates the Party-state's direct control over residents; and the intermediate actors interact with residents with different stakes in governance outcomes. The results reveal complex political mechanisms involving both strength-building and flexibility development in urban governance. Horizontal flexibility includes active adaptation of diverse governance means and modified forms of traditional governance strategies. In parallel, vertical power relations also take place through mass mobilisation and social control. These two mechanisms work together to reinforce the Party-state's political legitimacy in urban neighbourhoods.

\section{Deibei Tang is a senior associate professor and head of the Department of China Studies at Xi'an Jiaotong - Liverpool University. She is currently working on urbanization and neighbourhood governance in urban China (beibei.tang@xjtlu.edu.cn). This research is supported by the Xi'an Jiaotong-Liverpool University Research Development Fund (RDF 15-01-17).}

Manuscript received on 3 October 2018. Accepted on 6 May 2019. 


\section{References}

AUDIN, Judith. 2015. "Governing Through the Neighbourhood Community (shequ) in China: An Ethnography of the Participative Bureaucratisation of Residents' Committees in Beijing." Revue française de science politique 65: 85-110.

AUDIN, Judith. 2017. "Civic Duty, Moral Responsibility, and Reciprocity: An Ethnographic Study on Resident-volunteers in the Neighbourhoods of Beijing." China Perspectives 3(111): 47-56.

BAl, Haixing 白海星. 2018. “下好回迁社区管理'一盘棋"' (Xiahao huiqian shequ guanli "yipanqi," "Doing a good job" of governance in relocation communities). 中国经济网 Economy Daily, 12 September 2018, http://finance.jrj.com.cn/2018/09/14145425092592.shtml (accessed on 6 May 2019).

CAO, Shiyuan 操世元, and WANG Yongsheng 王永胜. 2010. “'村转居” 社区: 特点, 问题与建设方向" ("Cun zhuan ju" shequ: tedian, wenti yu jianshe fangxiang, Villages changing into residents' communities: characteristics, problems and development orientation). Xihua shifan daxue xuebao 西华示范大学学报 3: 28-34.

CHEN, Lin 陈琳. 2018. “昌平推动回迁社区向城市化转变” (Changping tuidong huiqian shequ xiang chengshihua zhuanbian, Pushing relocation communities to citizenisation transformation). 北京晨报 Beijing Morning Post, 11 January 2018.

CHUNG, Him, and Jonathan UNGER. 2013. "The Guangdong Model of Urbanisation: Collective Village Land and the Making of a New Middle Class." China Perspectives 3(95): 33-41.

FLEISCHER, Friederike. 2010. Suburban Beijing: Housing and Consumption in Contemporary China. Minneapolis: University of Minnesota Press.

GU, Chaolin, and Fulong WU. 2010. "Urbanization in China: Processes and Policies." China Review 10(1): 1-9.

HE, Shenjing, and George C.S. LIN. 2015. "Producing and Consuming China's New Urban Space: State, Market and Society." Urban Studies 52(15): 2757-73.

HE, Shenjing, and Junxi QIAN. 2017. "From an Emerging Market to a Multifaceted Urban Society: Urban China studies." Urban Studies 54(4): 827-46.

HO, Peter, and Richard L. EDMONDS (eds.). 2008. China's Embedded Activism: Opportunities and Constraints of a Social Movement. London: Routledge.

HSING, You-Tien. 2010. The Great Urban Transformation: Politics of Land and Property in China. New York: Oxford University Press.

HUANG, Meifang 黄梅芳, and JIANG Fuming 蒋福明. 2011. "'村改居'社 区文化建设现状的调查与思考一以湖南省衡阳市为例” ("Cun gai ju” shequ wenhua jianshe xianzhuang de diaocha yu sikao - yi Hunan sheng Hengyang shi wei li, Cultural life in "cun gai ju" communities - A case study in the city of Hengyang, Hunan province). Lilun xuexi 理论学习 10: 31-5.

LI, Si-Ming, and Youqin HUANG. 2006. "Urban Housing in China: Market Transition, Housing Mobility and Neighborhood Change." Housing Studies 21: 613-23.

LI, Xin 李金金. 2014. “村改居'社区治理中面临的困境” ("Cungaiju” shequ zhili zhong mianlin de kunjing, Challenges faced by "village to community" transition). 大同大学学报 Datong Daxue Xuebao 2: 16-8.

LI, Zhigang, and Fulong WU. 2006. "Socio-Spatial Differentiation and Residential Inequalities in Shanghai: A Case Study of Three Neighbourhoods." Housing Studies 21: 695-717.

LIN, George C.S. 2009. Developing China: Land, Politics and Social Conditions. London: Routledge.
LU, Yiyi. 2008. Nongovernmental Organizations in China: The Rise of Dependent Autonomy. New York: Routledge.

MA, Laurence J.C., and Fulong WU (eds.). 2005. Restructuring the Chinese City: Changing Society, Economy and Space. New York: Routledge.

MA, Qiusha. 2006. Non-governmental Organizations in Contemporary China: Paving the Way to Civil Society? London: Routledge.

POW, Choon-Piew. 2009. Gated Communities in China: Class, Privilege and the Moral Politics of the Good Life. London: Routledge.

READ, Benjamin L. 2003. "Democratizing the Neighbourhood? New Private Housing and Home-Owner Self-Organization in Urban China." The China Journal 49: 31-59.

READ, Benjamin L. 2007. "Inadvertent Political Reform via Private Associations: Assessing Homeowners' Groups in New Neighbourhoods." In Elizabeth J. Perry and Merle Goldman (eds.), Grassroots Political Reform in Contemporary China. Cambridge (MA) and London: Harvard University Press.

READ, Benjamin L. 2012. Roots of the State: Neighborhood Organization and Social Networks in Beijing and Taipei. Stanford: Stanford University Press.

SAICH, Tony. 2000. "Negotiating the State:The Development of Social Organizations in China." The China Quarterly 161(March): 124-41.

SARGESON, Sally. 2013. "Violence as Development: Land Expropriation and China's Urbanization." Journal of Peasant Studies 40(6): 1063-85.

State Council. 2016. “国务院关于实施支持农业转移人口市民化若干财政 政策的通知, 国发 [2016] 44号" (Guowuyuan guanyu shishi zhichi nongye zhuanyi renkou shiminhua ruogan caizheng zhengce de tongzhi, Notice on Implementing Financial Policies on Supporting the Citizenisation Process of Transforming Agricultural Population).

TANG, Beibei. 2015. "'Not Rural but Not Urban': Community Governance in China's Urban Villages." The China Quarterly 223(September): 724-44.

TOMBA, Luigi. 2005. "Residential Space and Collective Interest Formation in Beijing's Housing Disputes." The China Quarterly 184(December): 93451.

TOMBA, Luigi. 2014. The Government Next Door: Neighborhood Politics in Urban China. Ithaca: Cornell University Press.

UNGER, Jonathan (ed.). 2008. Associations and the Chinese State: Contested Spaces. Armonk, NY: Sharpe.

WANG, Hui. 2015. “加强基层党建, 推进回迁社区的社区化管理” (Jiaqiang jiceng dangjian, tuijin huiqian shequ de shequhua guanli, Strengthening Grassroots party-building, improving neighbourhood governance in relocation communities). Shunyi District Government Website, 19 December 2015.

WHYTE, Martin K. (ed.). 2010. One Country, Two Societies: Rural-Urban Inequality in Contemporary China. Cambridge MA: Harvard University Press.

WU, Ying 吴莹. 2017. “村委会'变形记': 农村回迁社区的基层组织建 设研究” (Cunweihui "bianxingji": Nongcun huiqian shequ de jiceng zuzhi jianshe yanjiu, Grassroots organisations in rural relocation communities). Shehui Fazhan Yanjiu 社会发展研究 5: 118-38.

XU, Qin 徐琴. 2012. “村转居”社区的治理模式” ("Cun zhuan ju” shequ de zhili moshi, Governance model of "cun zhuan ju" communities). Jianghai xuekan 江海学刊 2: 104-9.

YANG, Guihua 杨贵华. 2014. “转型与创生: “村改居'社区组织建设” (Zhuanxing yu chuangsheng: "cungaiju" shequ zuzhi jianshe, Governance in "village to community" neighbourhoods). Beijing: Shehui kexue wenxian chubanshe. 